\title{
Entrepreneurial Orientation and Performance of Small Business in Vryburg Region North West Province South Africa
}

\author{
Olabanji Oni ${ }^{1{ }^{1 *}}$, Edem Korku Agbobli ${ }^{2}$ and Chux Gervase Iwu $^{3}$
}

${ }^{1}$ Department of Business Management, Faculty of Management and Commerce, University of Fort Hare, Private Bag X1314, Alice, 5700, South Africa

${ }^{2}$ Department of Business Management, Faculty of Management Sciences, Central University of Technology, Private Bag X20539, Bloemfontein, 9300, South Africa

${ }^{3}$ Department of Entrepreneurship and Business Management, Faculty of Business and Management Sciences, PO Box 652, Cape Town, South Africa

\begin{abstract}
Small businesses play a significant role in job creation, economic growth and development, innovation, competitiveness and poverty alleviation that eventually improve business performance. The purpose of this study was to assess the association between Entrepreneurial orientation (EO) (innovativeness, risk taking, proactiveness and autonomy) and performance of small business in Vryburg area North West Province South Africa(SA). This quantitative study utilised questionnaire for data collection in a survey. The population were small business owners/managers in North West Province South Africa. Simple random sampling method was utilised to obtain participants for the study. The study utilised descriptive and inferential statistics. The result shows that only three attributes (innovativeness, risk taking and proactiveness) influence business performance while no association was found between autonomy and business performance. Additionally, positive relationship exists between the overall EO and the performance of small business. Empirically, the study contributes to the literature on EO and advance recommendations to improve the EO of small business in South Africa. The study recommends that policy makers, owners and managers of small business strategize on enterprise development and better business performance of small business in Vryburg area North West Province South Africa.
\end{abstract}

Keywords: Entrepreneurial orientation, Small business, Business Performance, Vryburg, South Africa, Socioeconomic development.

\section{INTRODUCTION}

Entrepreneurship is generally seen as the backbone of any economy - developed and emerging. Therefore, it can be argued that, given the acclaim of improving society's socioeconomic status, it is expected that the uptake of entrepreneurship results in increased employment, better standards of living and alleviation of poverty. In fact, examples abound in countries such as the United States of America, the United Kingdom and Japan where the small business sector is regarded as the engine of economic growth and job creation. This is seen to be the case because of the high levels of entrepreneurial orientation (EO) among the people in these countries leading Hznafi (2012) to point out that small businesses with advanced level of EO often perform better than small businesses with lesser level of EO. This being the case, entrepreneurship is expected to result in considerable socioeconomic development and growth in South Africa. The anticipation therefore is that small businesses will spearhead economic advancement of the Vryburg area

*Address correspondence to this author at the Department of Business Management, Faculty of Management and Commerce, University of Fort Hare, Private Bag X1314, Alice, 5700, South Africa; Tel: +27828391096; E-mail: ooni@ufh.ac.za
North West Province South Africa where this study was carried out.

There is an increasing interest in the association between EO and business performance. This is so for a handful number of reasons. Firstly, studies about the association between EO and business performance have revealed mixed results and in some cases inconclusive (Moreno and Casillas 2008; Paauwe 2009; Fairoz, Hirobumi and Tanaka (2010); Frank, Kessler and Fink 2010). For example, Chung-Wen (2008), in a study on leadership style, EO and business effectiveness of small business in Taiwan, found a significant positive association between proactiveness, innovation and business performance. Bahula (2012), Dada and Watson (2013) as well as Matchaba-Hove, Farrington and Sharp (2015) found a favourable link between EO and small business. Fairoz et al. (2010) studied the association between EO and business performance of SMEs in Hambantota District, Sri Lanka and found the degree of EO to be moderate in the majority of the SMEs in Sri Lanka. In addition, the study established a significant positive association between proactiveness, innovativeness, risk taking and overall EO with market growth. In contrast, Fairoz et al. (2010) found no significant nexus between risk taking, innovativeness, proactiveness and overall EO with 
profit, employment growth, sales and owner's satisfaction. Similarly, in South Korea, Lee and Lim (2009) as well as Moreno and Casillas (2008) found no significant link between EO and business performance. Furthermore, the association between EO and business performance is debatable. These contradictory views and the paucity of studies in developing countries necessitate the investigation of the link between EO and the small business performance in South Africa. In fact, a recent study by Haider, Asad and Fatima (2017) pointed out that there is limited study on the association between EO and business performance in developing countries. Moreover, drawing from the seminal work of Roskos and Klandt (2005), it is argued that the different levels of performance of small businesses could be explained in terms of their varying levels of entrepreneurial orientation. Giving the foregoing, the objectives of the research are: (1) to establish the level of EO among small businesses, (2) to investigate the nexus between innovativeness and performance of small business, (3) to examine the link between risk taking and performance of small business, (4) to assess the association between autonomy and performance of small business, (5) to measure the association between proactiveness and performance of small business and (6) to assess the association between overall EO and performance of small business. A major contribution of this paper is that it will add to the body of knowledge on EO in South Africa as well as advance recommendations to improve the EO of small business. The paper is structured as follows: the next section reviews the literature in which case we explore the definition of EO, the theory of EO, the relationship between EO and business performance of small businesses. Afterwards, the method and results are explained. The paper concludes with the implications of the findings, study limitations and directions for future research.

\section{LITERATURE REVIEW}

\section{Definition of Entrepreneurial Orientation}

Miller (2011) define EO as the strategic dimension for business performance. Rauch et al. (2009) view EO as entrepreneurial strategy decision processes used by top managers in creating the vision statement, mission statement and competitive advantage. According to Avlonitis and Salavou (2007), EO is an organisational concept that shows managerial capability through which businesses implement proactive and aggressive initiatives to gain competitive advantage. The extended definition of EO is affirmed by other researchers. Awang et al. (2009) as well as Lee and Lim (2009) define EO as firm's willingness to take risks, adopt innovative practices in producing goods or services, and proactively serving customers ahead of their competitors. EO also involves a disposition towards a desire to be in control of own business while adopting aggressive competitive posture towards rivals in the wake of the turbulent and hostile business environment.

Haider et al. (2017) point out that EO is represented by three dimensions. These are (1) innovativeness, (2) proactiveness and (3) risk taking. Similarly, Simon, Stachel and Covin (2011) argue that EO is measured using three attributes innovativeness, risk taking and proactiveness. Businesses that are entrepreneurially oriented are innovative, proactive and good in risk taking (Boso, Story and Cadogan 2013). Additionally, Fatoki and Oni (2014) measured the EO of immigrant entrepreneurs in South Africa using three elements namely innovativeness, risk taking and proactiveness. EO can also be measured using four attributes namely (1) risk taking, (2) autonomy, (3) innovativeness and (4) competitive aggressiveness (Lee and Lim 2009). Gautam (2016) as well as Hossain and Deewan's (2012) position is that that EO is represented by five dimensions namely (1) innovativeness, (2) risk taking, (3) autonomy, (4) proactiveness and (5) competitive aggressiveness. Essentially, EO implies a firm's behaviour characterised by innovativeness, risk-taking, proactiveness, competitive aggressiveness and autonomy seeking. For the purpose of this study, EO is measured using four variables innovativeness, risk taking, proactiveness and autonomy. However, competitive aggressiveness dimension is excluded from this study because it was assumed to be measured under proactiveness.

\section{Definition of a Small Business}

To put the study in context, it is necessary to provide a broad description of the small business environment. Although the term small business has gained global usage, it has different national, regional and even industry connotations. As a result, it is important to delve into its classification nationally and globally.

As stipulated in the NSBA (National Small Business Act) Act 102 of 1996 of South Africa as amended in 2003 and 2004, a small business is a firm with maximum of two hundred workers. However, according to the United States Small Business Administration 
(SBA) (2013), entities with less than five hundred workers are regarded as small businesses. While the European Commission (EC) (2009) recognises firms with a maximum of two hundred workers as a small business. Aside the head count method of classification for small businesses, there are other method used for classification of small businesses around the world i.e. classification through the technology used by firms.

Small businesses can also be referred to as medium or micro enterprises in South Africa as well as in the EU (NSBA, 1996, 2004; EC, 2009). This study therefore, recognises the South Africa definition of small business which classified firms with less than two hundred workers as small businesses, because this study is domicile and focused on the Small Scale Agricultural Enterprises in SA.

\section{Small Scale Agricultural Enterprises}

Small Scale Agricultural Enterprises operate in the agricultural sector which accounts for about $3 \%$ of South Africa's GDP and produces about $13 \%$ of the country's total exports. The sector is the main source of food supplies for the country's population of about 55 million people. In addition, the agricultural sector employs about $5.2 \%$ of the country's workforce (Statistics South Africa 2017).

In the Vryburg region, agriculture constitutes the biggest economic activity involving animal and crop production and related products. The Vryburg region is credited with the largest beef producing district in SA earning the nickname "the Texas of South Africa" for its beef producing capacity reminiscent of Texas, which is the largest cattle producing state in the US. Most businesses which engage in the agricultural activities are small and micro enterprises, hence the coinage small scale agricultural enterprises in the Vryburg region. Small scale agricultural enterprises therefore operate in an agricultural environment engaging in either crop or animal production or related activities in the Vryburg region. Employment in agriculture has been on the decline nationally and therefore affects Vryburg region as well (Statistics South Africa 2017). There is therefore an urgent need to stimulate growth in the sector by supporting especially small businesses which constitute the backbone of economic activities in the Vryburg region.

\section{Theory of Entrepreneurial Orientation}

Covin and Slevin (1989) drawing from Miller's (1983) concept posit that entrepreneurial organisations have leaders who have a willingness to pursue innovative and proactive strategies which might be risky but have high expected returns. Miller (1983) conceptualised three dimensions of EO innovativeness, risk taking, and proactiveness and they have been applied consistently in the literature. Lumpkin and Dess (1996) broadened the scopes that characterise EO to (5) through the inclusion of autonomy and competitive aggressiveness. First, innovativeness is described as a business environment that supports and encourages innovative models, creative process and experimentation that may lead to new techniques, technology or products, administrations or mechanical procedures and new opportunities for economic gain (Keh, Nguyen and Ng 2007; Chung-Wen 2008; Fairoz et al. 2010; Boso et al. 2013). Second, risk-taking involves investing in ventures with possibility of significant losses (Keh et al. 2007; Chung-Wen 2008; Kaya and Ağca 2009; Fairoz et al. 2010; Boso et al. 2013). Third, proactiveness relates to businesses acting strategically in order to gain first mover advantage by introducing new products and processes ahead of the competition (Keh et al. 2007; Chung-Wen 2008; Fairoz et al. 2010; Boso et al. 2013). Fourth, competitive aggressiveness reflects the intensity of a firm's combative postures to outperform its rivals in the market/industry (Lee and Lim 2009 and Fairoz et al. 2010). Last, autonomy encourages independent and autonomous action in firms which in turn promotes performance (Callaghan and Venter 2011).

\section{The Relationship between EO and Performance of Small Business}

Extant research findings regarding the link between EO and firm effectiveness increasingly seem to point towards positive relationship (Wiklund and Shepherd 2005; Covin, Kimberly, Green and Slevin 2006; Keh et al. 2007; Li, Huang and Tsai 2009; Kaya and Ağca 2009; Lee and Lim 2009; Lumpkin, Brigham and Moss 2010; Callaghan and Venter 2011; Soininen et al. 2012; Dada and Watson 2013). Additionally, Bahula (2012) found a moderate and strong positive association between EO and firm performance in the metals and engineering sector of SA. Furthermore, Haider et al. (2017) study of EO and business performance of manufacturing sector SMEs in Pakistan found a positive association between three EO variables innovativeness, proactiveness and risk taking and business performance. Chung-Wen (2008) study on leadership style, EO and business effectiveness of small business in Taiwan found a significant positive link between proactiveness, innovation and business 
performance. However, some researchers cast doubt on the universality of this positive nexus arguing that the research outcomes are mixed and therefore inconclusive (Moreno and Casillas 2008; Paauwe 2009; Fairoz et al. 2010; Frank et al. 2010). Moreno and Casillas (2008) argue that no significant association exists between EO and business performance. Notwithstanding the argument by Moreno and Casillas (2008), this study hypothesizes that:

H1: Positive association exist between innovativeness and business performance.

$\mathrm{H} 2$ : Positive link exist between risk taking and business performance.

H3: Positive association exist between proactiveness and business performance.

H4: Positive link exist between autonomy and business performance

\section{RESEARCH METHODS AND DESIGN}

\section{Research Design}

This paper employed quantitative design which was exploratory and descriptive in nature. Cooper and Schindler (2011) are of the view that exploratory research is useful when what is being investigated is unclear, ill-defined or fairly unknown. The study is descriptive because descriptive studies attempt to systematically provide answers to questions such as who, what, and how or information regarding a phenomenon through data collection summarised using statistical analysis. It may also aim at establishing relationships or the interactions between two or more variables (Cooper and Schindler 2011; Kumar et al. 2011).

\section{Study Population and Sampling Strategy}

The area of study was the Vryburg region North West Province with a population of 885 Small Scale Agricultural Enterprises. Simple random sampling technique a probability sampling method was employed to ensure that no business is favoured over the other. A sample size of 268 was computed using Raosoft sample size online calculator with confidence level of $95 \%$ and margin of error at $5 \%$.

\section{Data Collection}

The designed questionnaire for the study comprised of 3 sections namely biographical information, EO and business performance. EO was measured on the EO 9item scale which include dimensions namely, risk taking, autonomy seeking, innovativeness, proactiveness and competitive aggressiveness (Knight 2000; Lyon, Lumpkin and Gregory 2000; Matsuno, Mentzer and Özsomer 2002; Keh et al. 2007). Competitive aggressiveness was excluded from the modified scale because it was assumed to be measured under proactiveness. Secondly, it was reasoned that small businesses could hardly afford to lead competition wars by adopting aggressive posture towards their rivals. Business performance was measured using financial indicators (sales growth, gross profit and return on investment) and non-financial indicator (growth in the number of employees) over the past 5 years. The scale of business performance was adopted from (Fairoz et al. 2010 and Madhoushi et al. 2011). The questionnaire was pre-tested with 30 small business owners/managers. The pilot study was carried out to eliminate unclear questions and to improve face and content validity (Cooper and Schindler 2011). Cronbach alpha was used to ensure the internal consistency of the questionnaire with an alpha coefficient score of 0.7 or higher acceptable (Bryman and Bell 2011).

\section{Data Analysis}

Statistical Package for Social Sciences (SPSS) software version 24 was utilised to analyse the data for standard deviation, mean, correlation and regression analysis.

\section{RESULTS AND DISCUSSION}

\section{Response Rate}

The response rate was $74 \%$. From the two hundred and sixty-eight questionnaires distributed 198 questionnaires were filled correctly and returned by small business owners/managers.

Table 1: The Descriptive Statistics of EO Variables

\begin{tabular}{|c|c|c|}
\hline EO Variables & Mean & Standard deviation \\
\hline \hline Innovativeness & 3.55 & 1.05 \\
\hline Proactiveness & 3.15 & 0.92 \\
\hline Risk taking & 3.45 & 1.00 \\
\hline Autonomy & 3.60 & 1.03 \\
\hline Scale Mean & 3.44 & \\
\hline Standard deviation & 1.00 & \\
\hline Cronbach alpha & 0.73 & \\
\hline
\end{tabular}


Table 1 displays the outcomes of the descriptive statistics on entrepreneurial orientation. The autonomy element is the most vital dimension with a mean of 3.60. This means that small businesses actively encourage members to work independently and solve problems with minimal supervision. The next important dimension is innovativeness with a mean of 3.55. This is followed by risk taking with a mean of 3.45 . The next important and the lowest EO dimension is proactiveness which recorded a mean of 3.15. The scale mean in Table 1 is 3.44 signifies a high level of EO of small business because it is greater than 3.00 . This result is in line with a recent study by Koe (2016).

The descriptive statistics of business performance is presented in Table 2. The sales growth with a mean of 3.36 is the most significant factor. The next key variable is the gross profit with a mean of 3.24 . This is followed by the return on investment with a mean of 3.04. The employment growth recorded the lowest

Table 2: Descriptive Statistics of Business Performance Variables

\begin{tabular}{|c|c|c|}
\hline Business performance Variables & Mean & Standard deviation \\
\hline \hline Sales growth & 3.36 & 1.15 \\
\hline Gross profit growth & 3.24 & 1.11 \\
\hline Return on investment growth & 3.04 & 0.62 \\
\hline Employment growth & 1.84 & \\
\hline Scale Mean & 2.87 & \\
\hline Standard deviation & 0.98 & \\
\hline Cronbach alpha & 0.80 & \\
\hline
\end{tabular}

Table 3: Measurement of Items and Reliabilities

\begin{tabular}{|c|c|}
\hline Item & \\
\hline EO Component and Business Performance & \\
\hline $\begin{array}{l}\text { Innovativeness } \\
\text { Encouraging employees to come up with new ideas at the work place } \\
\text { Creatively solving problems concerning products/services } \\
\text { Encouraging development of unique ways of marketing products/services } \\
\text { Adopting new technology in making products/services } \\
\text { Introducing new products/services to the market }\end{array}$ & 0.838 \\
\hline $\begin{array}{l}\text { Proactiveness } \\
\text { First mover in terms of quality improvements } \\
\text { First mover in terms of introducing new products/services to the market } \\
\text { Belief that changes in the market creates a positive opportunity for doing business }\end{array}$ & 0.740 \\
\hline $\begin{array}{l}\text { Risk Taking } \\
\text { Risk and reward behaviour } \\
\text { Being bold but cautious in decisions that affect its future } \\
\text { Fear of financial loss } \\
\text { Implementation of plans only if it is very certain that they will work (dropped) }\end{array}$ & $\begin{array}{l}\text { Initial result } \\
0.506 \\
\text { New result } \\
0.701\end{array}$ \\
\hline $\begin{array}{l}\text { Autonomy } \\
\text { Encouraging individuals to think of ways of solving problems on their own } \\
\text { Employees being allowed to deviate from procedures when necessary } \\
\text { Supporting individuals or teams to work on their own without close supervision }\end{array}$ & 0.703 \\
\hline $\begin{array}{l}\text { Sales Growth } \\
\text { My business is satisfied with the sales growth over the past } 1 \text { to } 5 \text { years }\end{array}$ & 0.761 \\
\hline $\begin{array}{l}\text { Gross profit growth } \\
\text { My business is satisfied with the gross profit growth over the past } 1 \text { to } 5 \text { years }\end{array}$ & 0.740 \\
\hline $\begin{array}{l}\text { Return on Investment growth } \\
\text { My business is satisfied with the return on investment growth over the past } 1 \text { to } 5 \text { years }\end{array}$ & 0.792 \\
\hline $\begin{array}{l}\text { Employment growth } \\
\text { My business is satisfied with the employment growth over the past } 1 \text { to } 5 \text { years }\end{array}$ & 0.760 \\
\hline
\end{tabular}


Table 4: Correlation analysis Between EO Dimensions and Performance

\begin{tabular}{|c|c|c|}
\hline Model & EOdimensions & Business performance \\
\hline \hline & Innovativeness & $0.4986^{\star *}$ \\
\hline & Risk taking & $0.4567^{\star *}$ \\
\hline Pearson correlation & Proactiveness & $0.4705^{\star *}$ \\
\hline $\mathrm{N}$ & Autonomy & 0.0456 \\
\hline
\end{tabular}

** Correlation is significant at the 0.01 level ( 2 tailed).

mean of 1.84 . This is ascribed to the fact that small businesses usually employ few employees. The scale mean is 2.87; lower than 3.00 indicating a weak performance by small businesses.

The result of the reliability test to assess the internal consistency of all the variables using Cronbach Alpha is presented in Table 3. However, the reliability of the risk taking dimension appears to be rather low (0.506). This was improved to 0.701 by dropping one of the items comprising that dimension. All the values of the EO component and business performance are above 0.7 . This shows that the variables were internally consistent and the scales are reliable for further analyses.

Table 4 illustrates the correlation analysis between the four dimensions of EO and business performance. The Pearson correlation between business performance and innovativeness was significant at 0.4986 followed by proactiveness at 0.4705 and risk taking at 0.4705 . Nevertheless, no Pearson correlation was found between autonomy and performance of the business. This result supports Arshad et al. (2014) study which found a correlation between innovativeness, risk taking, proactiveness with business performance. The Pearson correlation between the overall EO and business performance recorded a moderate positive correlation of 0.4735 . This means if EO value increase/decrease, the value of business performance will increase/decrease. This result is consistent with Dada and Watson (2013) as well as $\mathrm{Li}$ et al. (2009) that found a direct nexus between $\mathrm{EO}$ and firm performance.

Table 5 show the results of the individual strength of the four dimensions of EO with business performance. The result shows that only three attributes influence business performance. Innovativeness $(p=0.01)$, proactiveness $(p=0.02)$ and risk taking $(p=0.03)$ are significant at $5 \%$ level. Therefore, $\mathrm{H} 1, \mathrm{H} 2, \mathrm{H} 3$ are supported. Autonomy $(p=0.24)$ is not significant with business performance. Therefore, $\mathrm{H} 4$ is not accepted.

The result of the multiple regression analysis on the four dimensions of EO with business performance is shown in Table 6 . There is a significant positive nexus between EO and firm performance since probability value $(0.014)$ is less than $5 \%$. This finding is in line with Soininen et al. (2012); Bahula (2012); as well as Matchaba-Hove et al. (2015) that found a direct association between $\mathrm{EO}$ and firm performance.

\section{CONCLUSION}

This study set out to gain a thorough insight into the level of EO and one hand and small businesses performance on the other hand. The ultimate goal was to help in facilitating improved performance of small businesses. The findings suggest that small

Table 5: Regression Analysis of the Individual Strength of EO Dimensions and Business Performance

\begin{tabular}{|c|c|c|c|}
\hline Model & Standardised coefficients (Beta) & T & P-value \\
\hline \hline Innovativeness & 0.286 & 2.689 & 0.01 \\
\hline Risk taking & 0.258 & 2.246 & 0.03 \\
\hline Proactiveness & 0.162 & 2.354 & 0.02 \\
\hline Autonomy & 0.079 & 1.176 & 0.24 \\
\hline
\end{tabular}

Dependent variable: Business performance. 
Table 6: Regression Analysis between Overall EO and Business Performance

\begin{tabular}{|c|c|c|c|c|c|c|c|}
\hline & \multirow[t]{2}{*}{ Model } & \multicolumn{2}{|c|}{$\begin{array}{l}\text { Unstandardised } \\
\text { coefficients }\end{array}$} & \multirow{2}{*}{$\begin{array}{c}\begin{array}{c}\text { Standardised } \\
\text { coefficients }\end{array} \\
\text { Beta }\end{array}$} & \multirow[t]{2}{*}{$\mathbf{T}$} & \multirow[t]{2}{*}{$p$ value } & \multirow[t]{2}{*}{ Model statistics } \\
\hline & & B & Std. error & & & & \\
\hline \multirow[b]{2}{*}{1} & (Constant) & 0.995 & 0.356 & -- & 2.797 & 0.006 & \multirow{2}{*}{$\begin{array}{c}\text { R }=0.637 \\
\text { Adjusted } R 2=0.396 \\
F=44.054 \\
p<0.05\end{array}$} \\
\hline & EO & 0.061 & 0.025 & 0.186 & 2.472 & 0.014 & \\
\hline
\end{tabular}

Dependent variable: Business performance.

businesses in the Vryburg area North West Province South Africa engage in EO activities and this orientation positively correlate with performance. The result also shows that only three attributes influence business performance. Innovativeness, risk taking and proactiveness while no association was found between autonomy and business performance. Additionally, there is a positive and moderate nexus between the overall EO and the performance of small business.

It has been argued that businesses would be more successful in achieving their growth and profitability goals if they are entrepreneurially oriented. The outcome of this research have provided some support for this position. In addition, the study has shown high manifestation of EO among small businesses which correlate with business performance. This study has shed light on the relationships between $\mathrm{EO}$ and firm performance. An intensive and co-ordinated intervention of government and non-government organisations in transforming the small business sector into the real engine of growth of the economy is imperative. Therefore, it is recommended that small business owners/managers be encouraged to integrate and cultivate cultures that support entrepreneurial orientation. The big four banks in South Africa, First National Bank (FNB), ABSA Bank, Standard Bank and Nedbank small business development units could also assist SMEs by providing regular advice on how to start, grow and manage small businesses. This will go a long way in reducing some of the socio-economic challenges of poverty, unemployment and inequality in SA. In addition, this will also reduce the failure rate, improve the performance as well as the sustainability of SMEs in South Africa.

\section{LIMITATIONS}

The study focused on Vryburg area North West Province South Africa, therefore, generalizing the findings of this study should be done cautiously.

\section{FUTURE RESEARCH}

Future research can be carried out in other regions of South Africa. In addition, studies can also look at EO and firm performance of the other key sectors (Manufacturing, Financial Services, Transport, Wholesale and Retail, Mining and Tourism) in South Africa. A future study may benefit from a qualitative approach owing to the need to uncover the real state of business performance in relation to EO and variables such as innovativeness, risk taking and proactiveness.

\section{REFERENCES}

Arshad, Azlin Shafinaz, Amran Rasli, Afiza Azura Arshad, and Zahariah Mohd Zain. 2014. "The impact of entrepreneurial orientation on business performance: A study of technologybased SMEs in Malaysia." Procedia-social and Behavioral Sciences 130: 46-53. https://doi.org/10.1016/j.sbspro.2014.04.006

Avlonitis, George J., and Helen E. Salavou. 2007. "Entrepreneurial orientation of SMEs, product innovativeness, and performance." Journal of Business Research 60(5): 566-575. https://doi.org/10.1016/j.jbusres.2007.01.001

Awang, Amran, Shaiful Annuar Khalid, Kamsol Mohamed Kassim Mohammad Ismail, Rozihana Shekh Zain, and Abdul Rashid Sintha Madar. 2009. "Entrepreneurial orientation and performance relations of Malaysian Bumiputera SMEs: The impact of some perceived environmental factors." International Journal of Business and Management 4(9): 84. https://doi.org/10.5539/ijbm.v4n9p84

Bahula, Mokgele Aubrey. 2012. "The impact of entrepreneurial orientation on performance in the metals and engineering industry." PhD dissertation, University of Pretoria, South Africa.

Boso, Nathaniel, Vicky M. Story, and John W. Cadogan. 2013. "Entrepreneurial orientation, market orientation, network ties, and performance: Study of entrepreneurial firms in a developing economy." Journal of Business Venturing 28(6): 708-727.

https://doi.org/10.1016/j.jbusvent.2013.04.001

Bryman, A. and Bell, E. 2011. Business Research Methods. Oxford: Oxford University Press.

Callaghan, Chris W., and R. Venter. 2011. "An investigation of the entrepreneurial orientation, context and entrepreneurial performance of inner-city Johannesburg street traders." Southern African Business Review 15 (1): 28-48.

Chung-Wen, Yang. 2008. "The relationships among leadership styles, entrepreneurial orientation, and business performance." Managing Global Transitions 6 (3): 257.

Cooper, D. R., and P. S. Schindler. 2011. "Qualitative research." Business research methods. USA: McGraw-Hill. 
Covin, Jeffrey G., and Dennis P. Slevin. 1989. "Strategic management of small firms in hostile and benign environments." Strategic Management Journal 10 (1): 75-87. https://doi.org/10.1002/smj.4250100107

Covin, Jeffrey G., Kimberly M. Green, and Dennis P. Slevin. 2006. "Strategic process effects on the entrepreneurial orientationsales growth rate relationship." Entrepreneurship theory and practice 30 (1): $57-81$. https://doi.org/10.1111/j.1540-6520.2006.00110.x

Dada, Olufunmilola, and Anna Watson. 2013. "Entrepreneurial orientation and the franchise system: Organisational antecedents and performance outcomes." European Journal of Marketing 47(5/6): 790-812.

https://doi.org/10.1108/03090561311306877

European Commission 2009. On the Implementation of Commission Recommendation of May 2003 Concerning the Definition of Micro, Small and Medium-sized Enterprises: Commission Staff Working Document. Brussels. Brussels, 2009. Retrieved June 06, 2017(https://www.google.co.za/ search? site $=$ andsource $=h$ pandq $=$ european + commission +20 09)

Fairoz, Fauzul Mafasiya, Takenouchi Hirobumi, and Yukiko Tanaka. 2010. "Entrepreneurial orientation and business performance of small and medium scale enterprises of Hambantota District Sri Lanka." Asian Social Science 6 (3): 34. https://doi.org/10.5539/ass.v6n3p34

Fatoki, Olawale, and Olabanji Oni. 2014. "The entrepreneurial orientation of immigrant entrepreneurs in South Africa." Mediterranean Journal of Social Sciences 5(20): 497-502 https://doi.org/10.5901/mjss.2014.v5n20p497

Frank, Hermann, Alexander Kessler, and Matthias Fink. 2010. "Entrepreneurial orientation and business performance." Schmalenbach Business Review 62(2): 175-198. https://doi.org/10.1007/BF03396804

Gautam, Prabin Raj. 2016. "Entrepreneurial orientation and business performance of handicraft industry: A study of Nepalese handicraft enterprises." International Journal of Small Business and Entrepreneurship Research 4 (2): 48-55.

Haider, S. H., M. Asad, and M. Fatima. 2017. "Entrepreneurial orientation and business performance of manufacturing sector small and medium scale enterprises of Punjab Pakistan." European Business and Management 3(2): 21-28. https://doi.org/10.11648/j.ebm.20170302.12

Hossain, Md, and Navid A. Deewan. 2012. Exploring the role of mobile service operators in the growth of micro enterprises in Urban Bangladesh. Masters Dissertation, Umea University, Sweden.

Hznafi 2012. Business performance of women-owned SMEs in Malaysia:Learning and EOand the Mediating Role of Competitive Advantage. PhD. Dissertation, University Utara, Malaysia.

Kaya, Harun, and Veysel Ağca. 2009. "Entrepreneurial orientation and performance of Turkish manufacturing FDI firms: An empirical study." Iktisat Isletme ve Finans 24(275): 115-133. https://doi.org/10.3848/iif.2009.275.3157

Keh, Hean Tat, Thi Tuyet Mai Nguyen, and Hwei Ping Ng. 2007. "The effects of entrepreneurial orientation and marketing information on the performance of SMEs." Journal of business venturing 22 (4): 592-611.

https://doi.org/10.1016/j.jbusvent.2006.05.003

Knight, Gary. 2000. "Entrepreneurship and marketing strategy: The SME under globalization." Journal of International Marketing 8(2): 12-32.

https://doi.org/10.1509/jimk.8.2.12.19620

Koe, Wei-Loon. "The relationship between Individual Entrepreneurial Orientation (IEO) and entrepreneurial intention. 2016. " Journal of Global Entrepreneurship Research, 6(1): 13. https://doi.org/10.1186/s40497-016-0057-8
Kumar, Vikas, Eli Jones, Rajkumar Venkatesan, and Robert P. Leone. 2011. "Is market orientation a source of sustainable competitive advantage or simply the cost of competing?" Journal of Marketing 75(1): 16-30. https://doi.org/10.1509/jmkg.75.1.16

Lee, Sang M., and Seongbae Lim. 2009. "Entrepreneurial orientation and the performance of service business." Service Business 3(1): 1 . https://doi.org/10.1007/s11628-008-0051-5

Li, Yong-Hui, Jing-Wen Huang, and Ming-Tien Tsai. 2009. "Entrepreneurial orientation and firm performance: The role of knowledge creation process." Industrial marketing management, 38(4): 440-449. https://doi.org/10.1016/j.indmarman.2008.02.004

Lumpkin, G. Tom, and Gregory G. Dess. 1996. "Clarifying the entrepreneurial orientation construct and linking it to performance." Academy of Management Review 21 (1): 135172.

https://doi.org/10.5465/amr.1996.9602161568

Lumpkin, G. Thomas, Keith H. Brigham, and Todd W. Moss. 2010. "Long-term orientation: Implications for the entrepreneurial orientation and performance of family businesses." Entrepreneurship and Regional Development 22(3-4): 241264. https://doi.org/10.1080/08985621003726218

Lyon, Douglas W., G. Thomas Lumpkin, and Gregory G. Dess. 2000. "Enhancing entrepreneurial orientation research: Operationalizing and measuring a key strategic decision making process." Journal of Management 26(5): 1055-1085. https://doi.org/10.1177/014920630002600503

Madhoushi, Mehrdad, Abdolrahim Sadati, Hamidreza Delavari, Mohsen Mehdivand, and Ramin Mihandost. 2011. "Entrepreneurial orientation and innovation performance: The mediating role of knowledge management." Asian Journal of Business Management 3(4): 310-316.

Matchaba-Hove, Tony, Shelley Farrington, and Gary Sharp. 2015. "The entrepreneurial orientation-Performance relationship: A South African small business perspective." The Southern African Journal of Entrepreneurship and Small Business Management 7(1): 36-68. https://doi.org/10.4102/sajesbm.v7i1.6

Matsuno, Ken, John T. Mentzer, and Ayşegül Özsomer. 2002. "The effects of entrepreneurial proclivity and market orientation on business performance." Journal of marketing 66(3): 18-32. https://doi.org/10.1509/jmkg.66.3.18.18507

Miller, Danny. 1983. "The correlates of entrepreneurship in three types of firms." Management science 29 (7): 770-791. https://doi.org/10.1287/mnsc.29.7.770

Miller, Danny. 2011. "Miller (1983) revisited: A reflection on EO research and some suggestions for the future." Entrepreneurship Theory and Practice 35(5): 873-894. https://doi.org/10.1111/j.1540-6520.2011.00457.x

Moreno, Ana M., and José C. Casillas. 2008. "Entrepreneurial orientation and growth of SMEs: A causal model." Entrepreneurship theory and practice 32(3): 507-528. https://doi.org/10.1111/j.1540-6520.2008.00238.x

Paauwe, J. 2009. "HRM and performance: Achievements, methodological issues and prospects". Journal of Management Studies, 46(1):129-142. https://doi.org/10.1111/j.1467-6486.2008.00809.x

Rauch, Andreas, Johan Wiklund, George T. Lumpkin, and Michael Frese. 2009. "Entrepreneurial orientation and business performance: An assessment of past research and suggestions for the future." Entrepreneurship theory and practice $33(3)$ : $761-787$. https://doi.org/10.1111/j.1540-6520.2009.00308.x

Republic of South Africa. 1996: National Small Business Act Number 102 of 1996. Pretoria: Government Printer. 
Roskos, S., and Klandt, H. 2005. The Influence of Entrepreneurial and Market Orientation on the Degree of Innovation and Success of New Ventures in Technology-oriented Industries. Eul.

Simon, Mark, Chanel Stachel, and Jeffrey G. Covin. 2011. "The effects of entrepreneurial orientation and commitment to objectives on performance." New England Journal of Entrepreneurship 14(2): 9-17. https://doi.org/10.1108/NEJE-14-02-2011-B001

Statistics South Africa 2017. Retrieved April 20, 2017 (http://beta2.statssa.gov.za/?page_id=1859)

Soininen, Juha, Minna Martikainen, Kaisu Puumalainen, and Kalevi Kyläheiko. 2012. "Entrepreneurial orientation: Growth and profitability of Finnish small-and medium-sized enterprises."
International Journal of Production Economics 140 (2): 614621.

https://doi.org/10.1016/.i.jpe.2011.05.029

United States, Small Business Administration, 2013. Table of Small Business Size Standards Marched to North American Industry Classification System Codes. Retrieved September 09, $2017 \quad$ (http://www.sba.gov/sites/default/files/files/ Size_Standards_Table.pdf).

Wiklund, Johan, and Dean Shepherd. 2005. "Entrepreneurial orientation and small business performance: a configurational approach." Journal of business venturing 20 (1): 71-91

https://doi.org/10.1016/j.jbusvent.2004.01.001

DOI: https://doi.org/10.6000/1929-7092.2019.08.07

(C) 2019 Oni et al.; Licensee Lifescience Global.

This is an open access article licensed under the terms of the Creative Commons Attribution Non-Commercial License (http://creativecommons.org/licenses/by-nc/3.0/) which permits unrestricted, non-commercial use, distribution and reproduction in any medium, provided the work is properly cited. 